\title{
Protein kinase C activation: isozyme-specific effects on metabolism and cardiovascular complications in diabetes
}

\author{
I. Idris, S. Gray, R. Donnelly
}

School of Medical and Surgical Sciences, University of Nottingham, \& Jenny O’Neil Diabetes Centre, Derbyshire Royal Infirmary, Derby, UK

Abstract Protein kinase $\mathrm{C}(\mathrm{PKC})$ is a family of multifunctional isoenzymes, activated by diacylglycerols (DAGs), which play a central role in signal transduction and intracellular crosstalk by phosphorylating at serine/threonine residues an array of substrates, including cell-surface receptors, enzymes, contractile proteins, transcription factors and other kinases. Individual isozymes vary in their pattern of tissue and subcellular distribution, function and $\mathrm{Ca}^{2+} /$ phospholipid cofactor requirements, and in diabetes there is widespread activation of the DAG-PKC pathway in metabolic, cardiovascular and renal tissues. In liver, muscle and adipose tissue, PKC isozymes have been implicated both as mediators and inhibitors of insulin action. Activation of DAG-sensitive PKC isoforms, such as PKC- $\theta$ and $\mathrm{PKC}-\varepsilon$, down-regulates insulin receptor signalling and could be an important biochemical mechanism linking dysregulated lipid metabolism and insulin resistance in muscle. On the other hand, atypical PKC isozymes, such as $\mathrm{PKC}-\xi$ and $\mathrm{PKC}-\lambda$, have been identified as downstream targets of PI-3-kinase involved in insulin-stimulated glucose uptake, especially in adipocytes.

Glucose-induced de novo synthesis of (palmitaterich) DAG and sustained isozyme-selective PKC ac- tivation (especially but not exclusively $\mathrm{PKC}-\beta$ ) has been strongly implicated in the pathogenesis of diabetic microangiopathy and macroangiopathy through a host of undesirable effects on endothelial function, VSM contractility and growth, angiogenesis, gene transcription (in part by MAP-kinase activation) and vascular permeability. Interventions that increase DAG metabolism (e.g. vitamin E) and/or inhibit PKC isozymes (e.g. the $\beta$-selective inhibitor LY333531) ameliorate the biochemical and functional consequences of DAG-PKC activation in experimental diabetes, for example improving retinal blood flow and albuminuria in parallel with reductions in membrane-associated PKC isozyme activities. Thus, a greater understanding of the functional diversity and pathophysiological regulation of PKC isozymes is likely to have important clinical and therapeutic benefits. [Diabetologia (2001) 44: 659-673]

Keywords Protein kinase C, PKC isoenzymes, insulin resistance, diacylglycerol, vascular complications, endothelial dysfunction, vascular permeability, PKC- $\beta$ PKC
Received: 8 January 2001 and in revised form: 12 February 2001

Corresponding author: Prof. R. Donnelly, Division of Vascular Medicine, University of Nottingham, Derbyshire Royal Infirmary, Derby, DE1 2QY, UK

Abbreviations: Akt, also called protein kinase B; bFGF, basic fibroblast growth factor; cAMP, cyclic adenosine monophosphate; DAG, diacylglycerol; ET-1, endothelin-1; ECM, extracellular matrix; GS, glycogen synthase; GSK-3 $\beta$, glycogen syn- thase kinase 3-beta; IRS-1, insulin receptor substrate-1; MAPkinase, mitogen-activated protein kinase; NO, nitric oxide; cNOS \& iNOS, constitutive \& inducible nitric oxide synthase; PA, phosphatidic acid; PC, phosphatidylcholine; PI-3-kinase, phosphoinositide-3-kinase; PKC, protein kinase $\mathrm{C}$ (c, conventional; n, novel; a, atypical groups); $\mathrm{PLA}_{2}$, phospholipase $\mathrm{A}_{2}$; PS, phosphatidylserine; TG, triglyceride; TGF $\beta$, transforming growth factor-beta; TNF- $\alpha$, tumour necrosis factor-alpha; VPF (or VEGF), vascular permeability factor. 

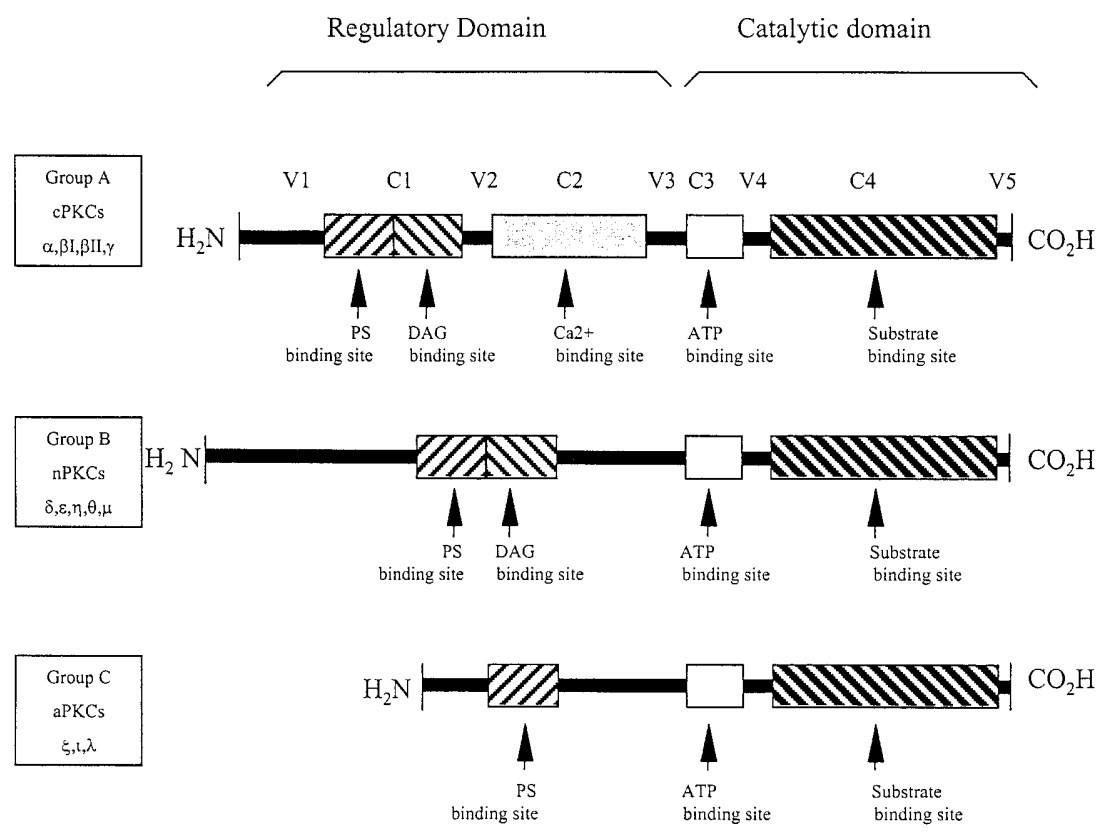

Fig. 1. The catalytic and regulatory domain structures of conventional, novel and atypical PKC isozymes with conserved regions ( $\mathrm{C} 1-\mathrm{C} 4)$ and variable regions (V1-V5), and binding sites for Calcium, phosphatidylserine (PS), DAG and ATP

\section{Protein kinase C (PKC): a family of multifunctional isoenzymes}

Adding and removing phosphate groups is an important physiological mechanism for regulating intracellular proteins, including enzymes, receptors and second messengers. Thus, a variety of receptor-mediated responses and metabolic pathways are activated and deactivated by intracellular kinases (enzymes that add phosphate groups) and phosphatases (enzymes that remove phosphate groups) which in turn are themselves regulated by extrinsic biochemical signals such as hormones and growth factors. Cellular kinases are broadly divided into two types: those that phosphorylate proteins at tyrosine residues (tyrosine kinases) and those that phosphorylate serine and threonine sites (serine/threonine kinases). There are three major serine/threonine kinases widely distributed in all tissues: cyclic AMP-dependant protein kinase (also known as protein kinase A, PKA), Akt (also known as protein kinase $\mathrm{B}, \mathrm{PKB}$ ) and the calcium-phospholipid activated kinase, protein kinase $\mathrm{C}$ (PKC).

$\mathrm{PKC}$ was first identified over 20 years ago as a single proteolytically-activated kinase in rat brain [1] but in fact PKC is a family of structurally and functionally related proteins derived from multiple genes (at least 3) and from alternative splicing of single mRNA transcripts (Fig.1) [2, 3]. Activation and translocation of PKC from the cytosol to the plasma membrane occurs in response to a transient increase in diacylglycerols (DAG) or exposure to exogenous tumour-promoting agents known as phorbol esters. The primary structure of PKC, a single polypeptide chain, can be divided into 4 conserved domains (C1-C4) separated by 5 variable regions (V1-V5) (Fig. 1). The $\mathrm{NH}_{2}$-terminal half of the polypeptide (i.e. $\mathrm{C} 1, \mathrm{C} 2, \mathrm{~V} 1, \mathrm{~V} 2$ and part of V3) constitutes the regulatory domain, while the $\mathrm{CO}_{2} \mathrm{H}$-terminal half (i.e. C3, C4, V4 and V5) forms the catalytic domain [4]. The functional domains are located in the conserved regions. Thus, the C1-region, which contains two cysteine-rich zinc finger-like regions, is responsible for DAG or phorbol ester binding. The C2-region is responsible for $\mathrm{Ca}^{2+}$-binding while the $\mathrm{C} 3$-region contains the ATP binding site and the C4-region contains the main catalytic site (Fig. 1).

A total of 12 isozymes of PKC have so far been cloned and characterised [5]. Brain and liver contain most PKCs but each isoform shows a different pattern of tissue distribution, substrate specificity and cofactor requirements (Table 1). The Group A (classical) PKC isoforms (cPKC- $\alpha,-\beta_{\mathrm{I}},-\beta_{\mathrm{II}}$ and $\left.-\gamma\right)$ are calcium- and phospholipid-dependent and possess the full primary amino acid sequence (C1-C4 and V1-V5). They are activated by phosphatidylserine (PS), $\mathrm{Ca}^{2+}$ and DAG (or phorbol ester). Group B (novel) PKCs (nPKC- $\delta,-\varepsilon,-\eta,-\theta$ and $-\mu$ ) lack the $\mathrm{C} 2$-region and are therefore calcium-independent but phospholipid-dependent; they require PS and DAG for activation. The Group C (atypical) PKC isoforms (aPKC- $\iota,-\lambda$ and $-\zeta$ ) also lack a C2-region, as well as one of the zinc finger-like cysteine-rich motifs in the $\mathrm{C} 1$ region, and are calcium and phospholipid independent. Both PKC- $\lambda$ and PKC- $\iota$ are species homologues. Although the atypical PKCs are dependent on the presence of PS for their catalytic activity, these isoforms are not activated by $\mathrm{Ca}^{2+}, \mathrm{DAG}$ or 
Table 1. Protein Kinase $C$ isoforms

\begin{tabular}{|c|c|c|c|c|c|}
\hline & \multirow[t]{2}{*}{ Isoform } & \multirow[t]{2}{*}{ Tissue Distribution } & \multicolumn{3}{|c|}{ Co-factor requirements } \\
\hline & & & $\overline{\mathrm{Ca}^{2+}}$ & DAG & PS \\
\hline Conventional cPKCs & $\begin{array}{l}\alpha \\
\beta_{\mathrm{I}} \\
\beta_{\mathrm{II}} \\
\gamma\end{array}$ & $\begin{array}{l}\text { widespread } \\
\text { widespread } \\
\text { widespread } \\
\text { brain }\end{array}$ & $\begin{array}{l}\sqrt{2} \\
\checkmark \\
\checkmark \\
\checkmark\end{array}$ & $\begin{array}{l}\checkmark \\
\checkmark \\
\checkmark \\
\checkmark\end{array}$ & $\begin{array}{l}2 \\
2 \\
2 \\
2\end{array}$ \\
\hline Novel nPKCs & $\begin{array}{l}\delta \\
\varepsilon \\
\eta \\
\theta \\
\mu\end{array}$ & $\begin{array}{l}\text { widespread } \\
\text { brain, heart } \\
\text { heart, skin, lung } \\
\text { muscle, brain, blood cells } \\
\text { lung epithelial cells }\end{array}$ & $\begin{array}{l}- \\
- \\
- \\
-\end{array}$ & $\begin{array}{l}\sqrt{2} \\
\checkmark \\
\checkmark \\
\checkmark \\
\checkmark\end{array}$ & $\begin{array}{l}\sqrt{2} \\
\checkmark \\
\checkmark \\
\checkmark \\
\checkmark\end{array}$ \\
\hline Atypical aPKCs & $\begin{array}{l}\zeta \\
\iota / \lambda *\end{array}$ & $\begin{array}{l}\text { widespread } \\
\text { kidney, brain, pancreas }\end{array}$ & $\begin{array}{l}- \\
-\end{array}$ & $\begin{array}{l}- \\
-\end{array}$ & $\begin{array}{l}-1 \\
d\end{array}$ \\
\hline
\end{tabular}

phorbol esters. In addition to the allosteric effectors, post-translational phosphorylation of $\mathrm{PKC}$ also appears to constitute an important mechanism for regulating PKC translocation and isozyme activity $[5,6]$.

Activation of one or more isoforms of PKC leads to a variety of biological responses, including changes in cell proliferation and differentiation, transmembrane ion transport, glucose and lipid metabolism, smooth muscle contraction and gene expression [7-9]. Very little is known about the functional specificity of different PKC isoforms and experimental work has been hampered by the lack of isoform-specific substrates for use in radioenzymatic assays. Pathophysiological studies have implicated PKC- $\beta$ and PKC- $\delta$ in hyperglycaemia-induced vascular dysfunction [10]. They have implicated PKC- $\zeta$ in insulin signalling [11-13] and abnormalities of cell growth and differentiation, including hyperplasia and hypertrophy [14], and PKC- $\varepsilon$ and PKC- $\theta$ in muscle insulin resistance [15-17].

$D A G$-mediated PKC activation in diabetes. Intracellular release of DAG is the primary step leading to activation and translocation of $\mathrm{PKC}$ and various species of DAG (varying in fatty acid composition) are generated from 4 principal sources (Fig. 2). These sources are, firstly, classical receptor-mediated, phospholipase C-catalysed hydrolysis of inositol phospholipids; secondly, the release of DAG from phospholipase D-mediated hydrolysis of phosphatidylcholine (PC); thirdly, through release of non-esterified fatty acids (NEFAs) from precursor lipids by the action of phospholipase $\mathrm{A}_{2}$; and, finally, de novo synthesis of DAG from phosphatidic acid (PA). This latter pathway is mainly responsible for hyperglycaemia-induced DAG formation in a range of metabolic and cardiovascular tissues in diabetes [18] but high glucose levels also increase the turnover of PC [19]. Thus, the fatty acid composition of excess DAGs that accumulate in diabetic tissues are consistent with a release of DAG from phospholipase D-mediat- ed hydrolysis of phosphatidylcholine and de novo synthesis of DAG from phosphatidic acid [20].

In addition, DAG-mediated activation of PKC is augmented by specific NEFAs of varying chain lengths. For example, non-esterified fatty acids and their CoA esters (especially arachidonic, oleic, linoleic and linolenic acids) appear to activate PKC synergistically with DAG [21, 22], and it has been suggested that cis-unsaturated fatty acids act as enhancer molecules [23]. Thus, in diabetes increased NEFA concentrations could enhance hyperglycaemia-induced PKC activation, independently of de novo synthesis of DAG [24].

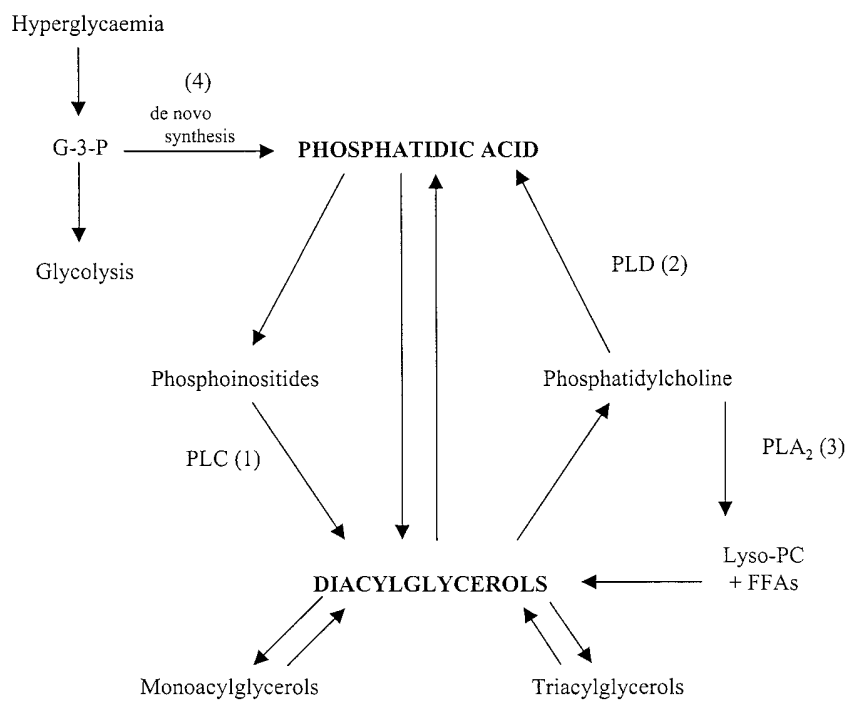

Fig. 2. Major reactions of animal glycerolipid metabolism. DAG is a central intermediate in the synthesis and turnover of all major glycerolipids. As such, DAGs are derived from multiple sources, including (1) phospholipase-C (PLC) mediated hydrolysis of phosphoinositides, (2) phospholipase-D (PLD) mediated hydrolysis of phosphatidylcholine (PC) by phosphatidic acid, (3) release of free fatty acids from precursor lipids through phospholipase $\mathrm{A}_{2}\left(\mathrm{PLA}_{2}\right)$ mediated, and (4) de novo synthesis of DAG from a glycolytic intermediate, glyceraldehyde-3-phosphate (G-3-P), under conditions of hyerglycaemia 


\section{Protein Kinase C isozymes - inhibitors \& mediators of insulin action}

Numerous lines of investigation suggest that the pathological accumulation of naturally occurring lipid metabolites could affect PKC activity and thus lead to dysregulated substrate phosphorylation and cellular function [25]. The PKC has been directly implicated in insulin signalling [26] and significantly increased PKC activity has been reported in liver [27] and muscle [28] tissues from diabetic humans and rats (Fig. 3). There is evidence that short-term exposure of various cell types to insulin leads to rapid formation of DAG [29], followed by activation and translocation of PKC [30], but increased membraneassociated PKC has been reported in humans (Fig. 3) and animals with diabetes characterised by hyperinsulinaemia [27, 28] and hypoinsulinaemia [31, 32], presumably reflecting tissue-selective and isoformselective differences in the insulin regulation of PKC.

The notion that PKC activation might phosphorylate and down-regulate one or more steps involved in glucose transport and metabolism emerged in the mid-1990s [33], supported by preliminary evidence that PKC phosphorylates the insulin receptor [34] and glycogen synthase [35]. In subsequent studies, changes in DAG-PKC signalling in liver, muscle and adipose tissues have been associated with insulin resistance due to ageing [36, 37], obesity [38], high-fructose and high-fat feeding $[15,16,39]$ as well as muscle denervation [40]. In addition, PKC has been implicated in the phenomenon of 'glucose toxicity', whereby sustained hyperglycaemia both in Type I (insulin-dependent) and Type II (non-insulin-dependent) diabetes mellitus exacerbates insulin resistance [41]. As well as glucose-induced formation of DAG enhancing phosphorylation and down regulation of the IR, increased glucose flux through the hexosamine biosynthesis pathway during hyperglycaemia has been shown to inhibit glucose transport through the activation of PKC [42]. The PKC has also been directly implicated in lipolysis and adipose tissue metabolism $[43,44]$ and transfected hepatocytes that over-express PKC become insulin resistant [45].

There has been considerable interest in the inter relationships between dysregulated lipid metabolism, fatty acid composition of membrane phospholipids and insulin resistance in skeletal muscle [46]. In both obesity and Type II diabetes, there are close inverse relation between muscle triglyceride (TG) content and in vivo insulin sensitivity $[47,48]$. Higher concentrations of DAG (an intermediate in the synthesis of TG and phospholipids) have been proposed as the key biochemical link, by PKC activation, between dysregulated lipid metabolism and greater muscle insulin resistance $[25,46]$. Thus, accumulation of lipids and their metabolites could inadvertently modulate PKC activity. Two novel PKCs, PKC- $\theta$ and PKC- $\varepsilon$,
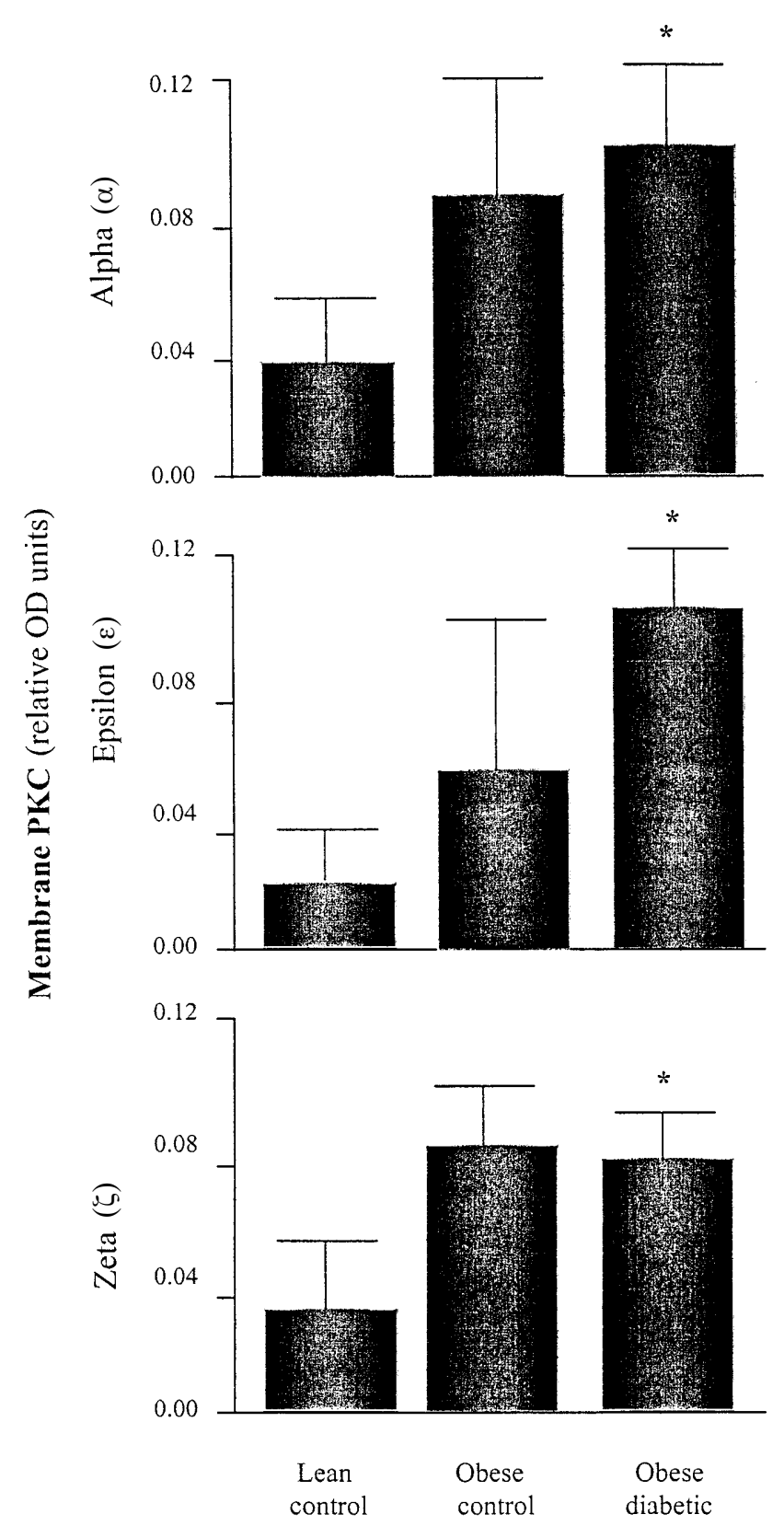

Fig.3. Immunodetection of membrane-associated PKC- $\alpha,-\varepsilon$ and $-\zeta$ in liver tissue from lean, obese and obese diabetic patients. Reproduced from reference 27

have been particularly implicated in this hypothesis. Both high-fructose and high-fat feeding are associated with increases in circulating and intramuscular TG content in rodents, and recent studies have shown isoform-selective increases in muscle PKC signalling in these dietary-induced models of insulin resistance [15, 16, 39] (Fig. 4). Moreover, treatment of high-fat fed rats with an antilipolytic drug, BRL49653, which reduced muscle DAG and non-esterified fatty acid mass, improved insulin sensitivity and reversed the diet-induced changes in nPKC expression [49]. Similarly, ex vivo experiments using human tissues showed that insulin is less capable of stimulating insu- 
A

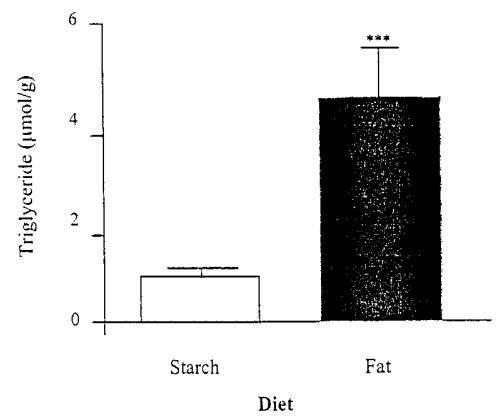

B

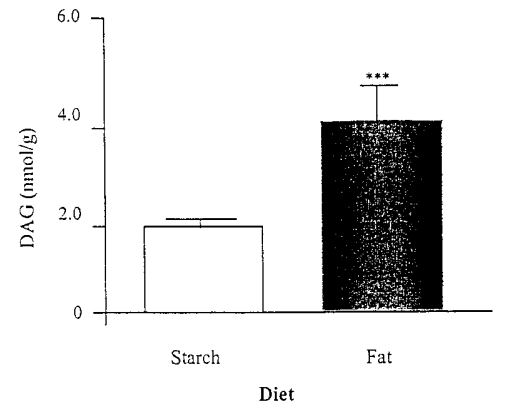

Fig. 4 (A-D). High-fat fed rats develop insulin resistance and increased DAG and triglyceride content of red gastrocnemius muscle relative to starch-fed controls $(\mathbf{A}, \mathbf{B})$. Correspondingly, the high-fat fed rats ( ) have increased PKC- $\theta$ (and PKC- $\varepsilon$ ) in the membrane fraction (relative to cytosol) of red gastrocnemius muscle compared with starch-fed controls $(\bigcirc)(\mathbf{C}, \mathbf{D})$. Reproduced with permission from reference 16

lin receptor substrate-1 (IRS-1) tyrosine phosphorylation, phosphoinositide-3-kinase (PI-3-kinase) activation and glucose transport in the skeletal muscle from obese subjects than from lean subjects [50]. Furthermore, PKC- $\theta$ has been particularly implicated in the inhibitory effects of fatty acids on insulin-induced PI-3-kinase activation [17].

$\mathrm{PKC}-\theta$ is one of the more recently identified $\mathrm{PKC}$ isoforms [51] and has a unique pattern of tissue distribution [52]. PKC- $\theta$ is expressed predominantly (and almost exclusively) in skeletal muscle, haematopoietic tissues, testis and platelets, and it is the major isoenzymic form of PKC in skeletal muscle [51]. A study has shown that expression of PKC- $\theta$ is threefold higher in tensor facia latae (TFL, an insulin-resistant white muscle) than in the soleus muscle (an insulin-sensitive red muscle) in the hindlimb of normal rats [15]. In addition, selective activation of muscle PKC- $\theta$ and $\mathrm{PKC}-\varepsilon$ has been associated with dietary-induced models of insulin resistance in normal rats $[15,16,39]$ and DAG-PKC activation after food intake in the muscles of obese Zucker rats [38], whereas in other experimental conditions associated with muscle insulin resistance (e.g. rodent models of hypertension and ageing) no changes in

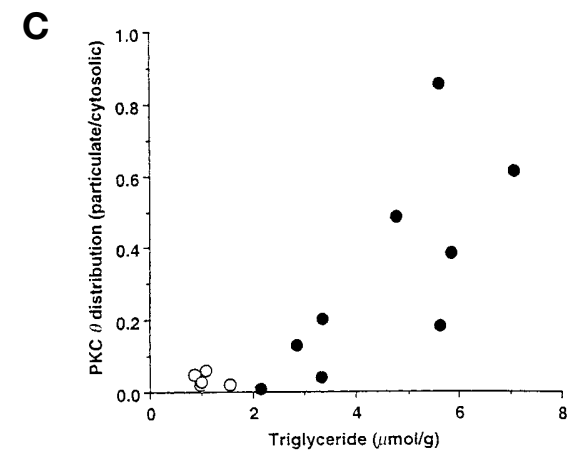

D

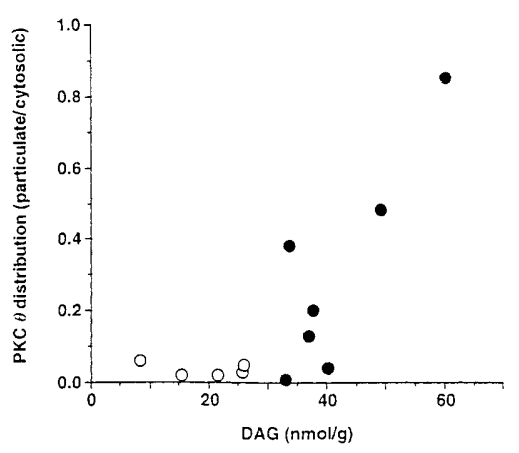

nPKC expression or subcellular distribution were observed [37,53]. Thus, specific changes in PKC- $\theta$ and $\mathrm{PKC}-\varepsilon$ seem to be associated with feeding and diet-related changes in muscle lipid content and insulin sensitivity.

Phosphorylation events seem to be particularly important in the mechanism of tumour necrosis factor- $\alpha$ (TNF- $\alpha$ ) induced insulin resistance, especially in adipocytes [54]. Recent evidence suggests that PKC mediates the inhibitory effect of TNF- $\alpha$ on insulin signalling by its effects on discrete PKC isoforms, e.g PKC- $\varepsilon$ [55] and/or PKC- $\beta$ and PKC- $\zeta[56,57]$. Similarly, increases in NEFA concentrations lead to a reduction in insulin-stimulated PI-3-kinase activity by the selective activation of PKC- $\theta$ [17].

Pharmacological studies of phorbol ester-induced $\mathrm{PKC}$ activation and the effects of non-specific PKC inhibitors (e.g. staurosporine-like compounds) have also provided important information. For example, several studies have shown that phorbol esters antagonise the effects of insulin [58] and inactivate the insulin receptor tyrosine kinase [59], whereas PKC inhibitors seem to enhance glucose-induced activation of hepatic glycogen synthase [60] and promote glucose uptake in isolated adipocytes [44]. Similarly, okadaic acid (a protein phosphatase inhibitor) promotes an insulin resistant state in adipocytes through a sustained serine/threonine phosphorylation of IRS-1 [61, 62]. In a PKC- $\beta$ knockout mouse model, Standaert et al showed modest increases in glucose uptake in specific tissues (i.e. $25 \%$ in soleus muscle and $50-100 \%$ in adipocytes), consistent with a small reduction in the inhibitory effect of one PKC isozyme on glucose homeostasis [63]. 
Previous review articles found some difficulty reconciling apparently contradictory research showing roles for PKC both as a mediator and inhibitor of insulin action [26] but it now seems clear that distinct PKC isoforms serve widely different functions and do so in a tissue-dependent manner. Thus, whereas the $\mathrm{Ca}^{2+}$-independent isozymes, PKC- $\theta$ and PKC- $\varepsilon$, exert negative regulatory effects on insulin action, especially in skeletal muscle, the atypical PKCs such as PKC- $\zeta$ which are not activated by DAG, appear to be stimulated by polyphosphoinositides derived from PI-3-kinase activation by insulin, for example in adipose tissues [12, 13, 64, 65]. Insulin could also affect mRNA expression of individual PKC isozymes [66]. It is therefore likely that some PKC isoforms (e.g. PKC- $\zeta$ ) function as mediators of insulin action downstream of PI-3-kinase, while other PKCs (e.g. PKC $-\theta$ and $\mathrm{PKC}-\varepsilon$ ) have negative regulatory effects on insulin signalling $[12,13,65]$.

PKC-mediated phosphorylation and insulin receptor function. The IR tyrosine kinase on the $\beta$-subunit is an important target for PKC phosphorylation [55, 67] and recent work has shown that PKC- $\beta_{\mathrm{I}}$ and $-\beta_{\mathrm{II}}$ exert strong inhibitory effects on the IR tyrosine kinase - autophosphorylation step [68]. A study has also shown that glucose and phorbol ester-induced activation of $\mathrm{PKC}-\alpha,-\varepsilon$ and $-\xi$ causes a rapid inhibition of IR tyrosine kinase activity [69], whereas PKC- $\alpha,-\delta$ and $-\theta$ require IRS- 1 in order to inhibit the IR tyrosine kinase in HEK 293 cells [70]. The PKC- $\theta$ has an especially strong inhibitory effect on insulin receptor signalling by the phosphorylation of IRS-1 [70] and recent work has shown that serine residues 994 and $1023 / 25$ on the IR are particularly important for PKC- $\theta$ and PKC- $\beta_{\mathrm{II}}$ mediated inhibition of IR autophosphorylation [71].

The PKC-mediated phosphorylation is clearly an important mechanism of hyperglycaemia-induced IR inhibition $[41,69,72]$ and a PKC inhibitor prevents glucose-related down-regulation of the IR tyrosine kinase [73]. A recent clinical study examining PKC pathways in skeletal muscle concluded that the decreased tyrosine kinase activity of the IR in obese subjects was due to hyperphosphorylation on serine/ threonine sites mediated by PKC, especially PKC- $\beta$ [74]. PKC activation also increases IR degradation [75].

In the immediate down stream signalling events following IR stimulation, PKC phosphorylates and modulates the IRS proteins [62, 72], particularly at the serine 612 position [76], and inhibits insulin-stimulated Akt1 and Akt3 activity [77]. Although some PKC isoforms seem to exert a negative regulatory effect on insulin signalling, others, including PKC- $\zeta$ and $\mathrm{PKC}-\lambda$, are among several serine/threonine kinases (including $\mathrm{Akt} / \mathrm{PKB}$ ) that have been identified as down stream targets of PI-3-kinase $[12,13]$. On the other hand, PKC- $\theta$ is selectively activated by a rise in circulating NEFA concentrations and leads to a reduction in insulin-stimulated PI-3-kinase activity [17].

$P K C$ and glucose transport. Although GLUT transporter proteins are not directly regulated by phosphorylation, there is evidence that PKC-related phosphorylation events, perhaps involving intermediate substrates, indirectly influences glucose uptake. For example, pharmacological studies have shown increased glucose transport (secondary to increased GLUT1 and GLUT4 expression) in parallel with decreased PKC activity [78], and GLUT4 trafficking pathways could be regulated by PKC [79]. On the other hand, early studies suggested that PKC activation, whether by DAG or phorbol esters, increases glucose uptake [44, 80], even though more recent work by the same group has shown that only atypical PKC isozymes (e.g. PKC- $\zeta$ ) are involved in mediating insulin-stimulated glucose transport [12, 65]. Thus, initial, apparently contradictory findings can be explained on the basis that certain PKC isoforms, such as PKC- $\zeta$ and PKC- $\lambda$, have been identified as down stream targets of PI-3-kinase [12, 13], while DAG-sensitive PKCs (i.e. certain cPKCs and nPKCs) have negative regulatory effects on insulin signalling [65]. Thus, different isoenzymes of PKC appear to function separately as mediators or inhibitors of insulin action.

$P K C$ and glycogen synthase activity. Glycogen synthase (GS) is the rate-limiting enzyme involved in non-oxidative glucose metabolism, which is the major pathway of glucose disposal in resting skeletal muscle. GS exists in two interconvertible forms: an inactive phosphorylated form and an active dephosphorylated form. PKC is one of several kinases that phosphorylate GS directly [35], and individual PKC isoforms could reduce GS activity in muscle [28], but in the liver PKC- $\alpha,-\beta$ and $-\gamma$ phosphorylate glycogen synthase kinase- $3 \beta$ (GSK- $3 \beta$, the most potent kinase regulating hepatic GS activity), which in turn leads to a reduction in glycogen synthesis [81].

\section{PKC and insulin secretion}

An increase in intracellular $\mathrm{Ca}^{2+}$ in the beta cell in response to insulin secretagogues, including glucose, directly triggers exocytosis of the insulin granules. Second messengers, such as cAMP and DAG, increase insulin release through protein phosphorylation events mediated by PKA and PKC, respectively. Apart from increasing intracellular $\mathrm{Ca}^{2+}$ levels, these phosphorylation reactions enhance insulin release by heightening the $\mathrm{Ca}^{2+}$ sensitivity of the secretory apparatus [82]. Recent work has shown that PKA and 
PKC act synergistically on different steps upstream of exocytosis in the insulin secretory cascade [83].

Conventional and atypical isoforms of PKC are expressed in pancreatic $\beta$-cells, including the most recently cloned isoenzyme, $\mathrm{PKC}-\iota$ [84]. The $\mathrm{PKC}-\zeta$ is particularly important in carbachol-stimulated insulin release [85], and there is increasing evidence that $\mathrm{PKC}$ activation regulates the second-phase insulin secretory response [86]. (The first phase insulin response is primarily cAMP and $\mathrm{Ca}^{2+}$-dependent). Extrinsic factors such as endothelin-1 could augment insulin secretion through PKC-dependent pathways [87].

\section{Hyperglycaemia-induced PKC activation: a central pathway in the development and progression of diabetic vascular complications}

$D A G-P K C$ signalling in vascular tissues exposed to high glucose. Several biochemical mechanisms have been proposed to explain the structural and functional abnormalities associated with prolonged exposure of cardiovascular tissues to hyperglycaemia (Table 2), but this review will focus on the clinical, pathophysiological and therapeutic significance of glucose-induced DAG-PKC activation.

Glucose is transported into vascular cells by GLUT1 transporters and then metabolised mainly through glycolysis $(<5 \%$ of intracellular glucose is metabolised by the aldose reductase pathway, even under conditions of hyperglycaemia). The GLUT1 is up-regulated by high extracellular glucose concentrations and hypoxia [88], and the increased glycolytic flux results in increased de novo synthesis of DAG (Fig. 2). Increases in total DAG, and palmitate-rich DAG, have been reported in various cells and tissues from diabetic animals and humans, including the retina, aorta, heart and glomeruli $[10,89,90]$ (Table 3 ). A study has recently shown that fatty acids play an important role in modulating PKC activity in vascular cells, independently of de novo DAG synthesis, and that increased formation of DAG, by itself, is insufficient to activate PKC [24]. The NEFAs also increase the affinity of cPKCs for $\mathrm{Ca}^{2+}$ such that PKC activation occurs even at basal $\mathrm{Ca}^{2+}$ concentrations [91].

Thus, hyperglycaemia, even acutely [92], leads to increased DAG-PKC signalling in a variety of cardiovascular and renal tissues (Table 3). Investigators at the Joslin Diabetes Centre in Boston first made the important observation of differential isoform and tissue-dependent PKC responses to hyperglycaemia [10]. They showed that hyperglycaemia-induced DAG is rich in palmitate and speculated that different species of DAG preferentially activate one or more $\mathrm{PKC}$ isoenzymes in different tissues, for example, PKC- $\beta_{\mathrm{II}}$ in the heart and aorta, PKC- $\alpha,-\beta_{\mathrm{II}}$ and
Table 2. Major pathways implicated in the pathogenesis of hyperglycaemia-induced vascular injury

- Non-enzymatic glycation: formation of advanced glycation endproducts (AGEs)

- Polyol pathway : aldose reductase-mediated changes in sorbitol and myoinositol

- Protein Kinase C activation via hyperglycaemia-induced DAG accumulation

- Redox potential alterations : changes in free radicals and oxidation state

$-\varepsilon$ in the retina, and PKC- $\alpha,-\beta_{\mathrm{I}}$ and $-\delta$ in glomerular cells [93]. It is interesting that PKC- $\beta_{\mathrm{II}}$ is the dominant isoform response in macrovascular tissue, including smooth muscle and endothelial cells, and the retina $[10,94]$, whereas in glomerular cells $\mathrm{PKC}-\beta_{\mathrm{I}}$ is predominantly overexpressed in response to high glucose [95]. Although a wide range of tissue and cell types show increased DAG-PKC signal transduction under experimental conditions of diabetes (Table 3), these changes are by no means universal. For example, PKC activity in the brain and peripheral nerve tissue is not changed [96].

Accumulation of DAG in vascular tissues in hyperglycaemic states is ameliorated by $D$ - $\alpha$-tocopherol (vitamin E), which activates DAG kinase and facilitates the conversion of DAG to PA [97, 98]. Several studies have shown that glucose-induced PKC activation is attenuated by vitamin $\mathrm{E}[94,99]$ and that the functional consequences of PKC activation are correspondingly reversed, for example in the kidney [95] and retina [100].

Activation of the DAG-PKC pathway, by the phosphorylation of many different PKC substrates, has a number of undesirable effects on pathophysiological processes which contribute to the long-term structural and functional abnormalities associated with microvascular and macrovascular complications (Fig.5).

Endothelial dysfunction \& monocyte adhesion. The vascular endothelium plays a crucial role in regulating haemostasis (coagulation and fibrinolysis), blood vessel tone, vascular permeability and local platelet activation. Endothelial dysfunction and endothelial cell activation, involving many of these processes, are early features of diabetes which precede the development of overt microangiopathy and macroangiopathy [101, 102]. Apart from nitric oxide (NO), a huge array of substances is released from endothelial cells in response to biochemical and physical stimulation, for example angiotensin II, endothelin-1 (ET-1), $\mathrm{TGF} \beta$, vascular endothelial growth factor (VEGF), plasminogen activator inhibitor-1, prostaglandins and von Willibrand factor (vWf) protein. The vWf has been used as a surrogate marker of endothelial cell activation which correlates with macrovascular death rates in diabetes [103]. 


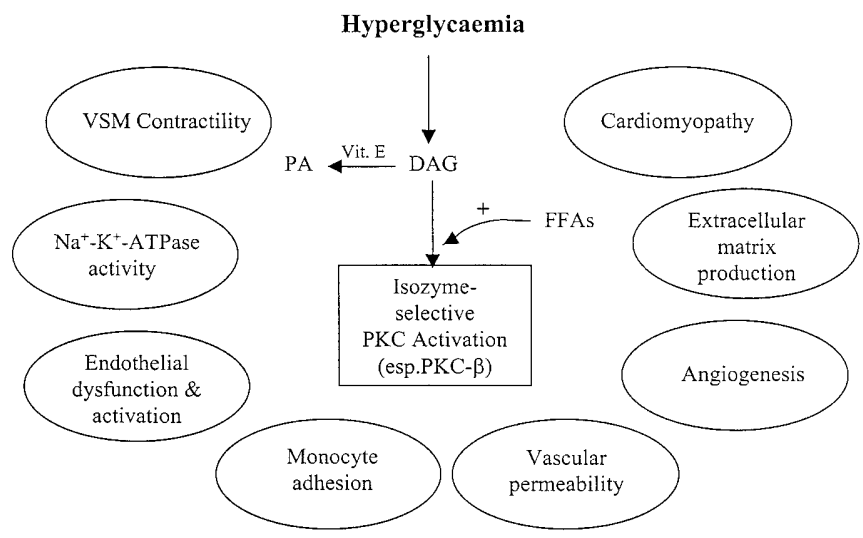

Fig. 5. Increased DAG-PKC activation in vascular cells and tissues exerts a variety of undesirable effects which contribute to the functional and structural abnormalities characteristic of diabetic microangiopathy and macroangiopathy. Some of these effects can be ameliorated by vitamin E, a DAG kinase activator, or isozyme-specific PKC inhibitors such as LY333531

There is increasing evidence that PKC activation is an important biochemical mechanism in hyperglycaemia-related and diabetes-related endothelial dysfunction. For example, impaired (NO-mediated) vasodilation and increased release of ET-1 in the retina involve PKC-mediated inhibition of constitutive nitric oxide synthase (cNOS) [104] and induction of ET-1 gene expression $[105,106]$. This is clinically important because retinal blood flow decreases before overt retinopathy develops [107] and PKC inhibition restores retinal microvascular haemodynamics [89]. In contrast, in the kidney vasculature, $\mathrm{PKC}$ activation could increase (by iNOS induction) or decrease NO production according to cell type, tissue location and duration of diabetes [108, 109]. Individual isoforms of $\mathrm{PKC}$ regulate iNOS expression in both a positive and negative manner [110]. Both PKC activation and increased NO production also contribute to the hyperpermeability response to increased glucose [111].

Activated normal platelets produce local vasodilation by the release of platelet-derived ADP, which in turn stimulates endothelial release of NO, but in diabetic patients this pathway is impaired. Recent work has shown that impaired platelet-mediated vasodilation due to hyperglycaemia is caused by increased DAG levels and PKC-mediated stimulation of phospholipase $\mathrm{A}_{2}\left(\mathrm{PLA}_{2}\right)$ activity [112]. In addition, the reduced $\mathrm{N}^{+}-\mathrm{K}^{+}$-ATPase activity in diabetes is explained by PKC-dependent increases in cytosolic $\mathrm{PLA}_{2}$ and prostaglandin $\mathrm{E}_{2}$ concentrations $[113,114]$.

Endothelins are particularly important in the pathogenesis of diabetes complications [115], especially in the retina, and PKC activation increases ET-1 gene expression $[105,106]$. A study has shown that overexpression of PKC- $\beta_{\mathrm{II}}$ and PKC- $\delta$ (but not $\mathrm{PKC}-\zeta)$ enhanced, in parallel, PKC activities, and basal and glucose-induced ET-1 mRNA expression by at least twofold [105]. Similarly, phorbol esters increased ET-1 release and PKC inhibition decreased ET-1 release from aortic and pulmonary endothelial cells [116]. The effects of ET-1 on the heart, including calcium homeostasis, myocyte contractility and the growth-promoting effects of ET-1, seem to be mediated by PKC- $\varepsilon$ [117].

Monocyte binding to endothelial cells is an important early event in atheroma formation and one that is enhanced in diabetes [118]. A recent clinical study has shown that membrane-associated PKC activity is increased in monocytes from diabetic patients and that total PKC activity and expression of the glucose-sensitive PKC- $\beta_{\mathrm{II}}$ isoform decreased by $40 \%$ under euglycaemic conditions [92]. Because increased PKC activity in monocytes enhances their adhesion to the vascular wall, increases fibrinogen binding [119] and promotes differentiation into macrophages [120], augmentation of this signal transduction pathway could contribute to the accelerated progression of atheroma in patients with diabetes. The adhesion molecules most involved in monocyte-endothelial cell interactions are E-selectin, intercellular adhesion molecule-1 (ICAM-1) and vascular adhesion molecule-1 (VCAM-1). High glucose up-regulates ICAM-1 protein and mRNA expression, but not VCAM-1, by a PKC-NFкB-dependent pathway [121].

Vascular smooth muscle contractility, growth \& differentiation. The PKC plays a pivotal role in the signal transduction of vascular smooth muscle (VSM) cell contraction [122], and the increased contractile responsiveness of VSM observed in diabetes has been attributed, in part, to sustained hyperglycaemia-induced PKC activation [123]. Increased PKC activity in VSM cells occurs within minutes of exposure to high extracellular glucose levels $(15-20 \mathrm{mmol} / \mathrm{l})$, and the PKC response quickly reverses if glucose levels fall [124]. A study has shown that, in contrast to the transient $\mathrm{PKC}$ response to pressor hormone stimulation, glucose-induced PKC activation in VSM is much more sustained [124]. Increases in PKC activity in VSM have been implicated in the regulation of cell-surface hormone receptor density, intracellular signalling responses to pressor hormones, ion channel activity, phosphorylation of myofibrillar proteins, expression of the actin-myosin regulatory protein caldesman and intracellular $\mathrm{pH}[122,125]$. Overexpression of PKC- $\beta_{\mathrm{II}}$ in a transgenic heart model led to phosphorylation of troponin-I and decreased myofilament responsiveness to $\mathrm{Ca}^{2+}[126]$. Short-term exposure of VSM cells to high glucose also increases vascular permeability factor (VPF) mRNA by a PKC- $\beta$ dependent pathway [127]. The VPF is essentially an endothelial cell-selective mitogen involved in angiogenesis and vascular permeability. 
Table 3. Diabetes-related activation of the DAG-PKC pathway in vascular cells and tissues

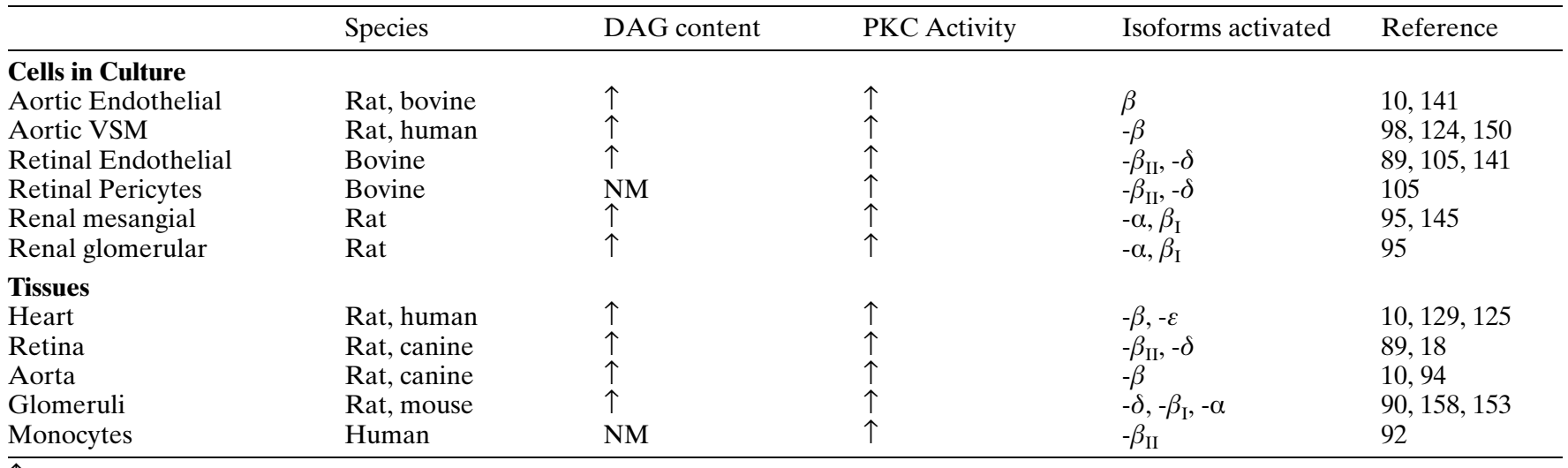

$\uparrow=$ increased $; \mathrm{NM}=$ not measured

PKC also plays an important role in VSM and cardiomyocyte growth and differentiation, partly by activating the mitogen-activated protein (MAP) kinases which in turn phosphorylate transcription factors and alter the balance of gene expression [128]. This pathway can affect cell phenotype, promote cell division or increase the production of extracellular matrix material. In the diabetic heart, PKC activation seems to be particularly important in remodelling [129]: PKC- $\alpha$ and $-\beta$ have been implicated in cardiac hypertrophy [130] and PKC- $\varepsilon$ seems to have a protective effect in myocardial preconditioning [131]. Overexpression of PK- $\beta_{\mathrm{II}}$ in a transgenic mouse model led to increased left ventricular (LV) hypertrophy and fibrosis, with reduced LV function, accompanied by up regulation of mRNA expression for fetal myosin heavy chain, $c$-fos, TGF $\beta$ and collagen types IV and VI [130]. Activation of PKC- $\zeta$ has been shown to be an essential step in mitogenic signal transduction [132], for example in mediating the growth-promoting effects of angiotensin II on VSM [133] and pathological conditions such as hypoxia selectively activate PKC isoforms in cardiomyocytes [134].

A variety of polypeptide growth factors have been shown to be important in the physiological regulation of VSM contraction, migration and growth, including competence growth factors such as platelet-derived growth factor (PDGF) and progression factors such as insulinlike-growth factor-1 (IGF-1). Changes in intracellular $\mathrm{Ca}^{2+}$ and $\mathrm{pH}$ are important modulators of growth factor-induced mitogenesis and contraction but the underlying pathways are linked to PKC activation [135]. The VSM cell apoptosis induced by reactive oxygen species is also PKC-dependent [136].

Vascular permeability and angiogenesis. The loss of endothelial barrier function is an early pathophysiological feature of diabetic angiopathy. Various stimuli, including high glucose, activate second messenger systems in endothelial cells, particularly PKC, which initiate intracellular contractile events, shape change ('rounding up' of endothelial cells) and leakage of macromolecules. The PKC-mediated phosphorylation and relaxation of cytoskeletal and adhesion proteins, such as caldesmon and vimentin, as well as up regulation of NOS, account for the increase in vascular permeability in response to high glucose [111, 137] and $\mathrm{PKC}-\beta_{\mathrm{I}}$ overexpression augments phorbol ester-induced hyperpermeability [138]. The PKC- $\alpha$ has been implicated in the permeability response to high glucose, an effect that was abolished using a specific antisense oligonucleotide [139].

The cytokine VPF (also known as vascular endothelial growth factor, VEGF, or vasculotropin) is a homodimeric glycoprotein secreted by VSM cells that exerts potent effects on vascular permeability and angiogenesis. The VPF gene expression is upregulated in VSM cells exposed to high glucose through a PKC-dependent pathway [127] and increased VPF levels have been detected in ocular fluid of patients with diabetic retinopathy [140]. The VPF is the principal mediator of hypoxia-stimulated angiogenesis and neovascularisation in the eye but also plays a key role in fetal development, wound healing, collateral vessel formation and tumourgenesis. The VPF binds to one of two cell-surface receptors: KDR/flk-1, expressed only on endothelial cells, especially in the eye, and flt-1, expressed on endothelial and non-endothelial cell types. The VPF binding to either receptor triggers phosphoinositol hydrolysis, with the release of DAG and activation of PKC$\alpha,-\beta$ and $-\delta$ [141], and VPF-induced cell proliferation is blocked by non-specific and $\beta$-selective PKC inhibitors but not by an antisense oligonucleotide to PKC$\alpha$ [141]. Intra-vitreal administration of VPF increases membrane translocation of PKC- $\alpha, \beta_{\mathrm{II}}$ and $-\delta$, and the VPF-induced permeability and cell growth responses are abolished by selective PKC- $\beta$ inhibition [142].

There is a synergistic interaction between the angiogenic effects of VPF and basic fibroblast growth factor (bFGF) which is at least partly due to up regulation of KDR/flk-1 expression by bFGF through a 
PKC and MAP kinase-dependent pathway not involving PKC- $\beta$ [143]. Thus, PKC signalling appears to be central to several pathways involved in the regulation of angiogenesis and new vessel formation [144].

Glomerulopathy and extracellular matrix deposition. Expansion of the glomerular mesangium is an early feature of diabetic nephropathy, and hyperglycaemia promotes increased synthesis and reduced degradation of extracellular matrix (ECM) components. Glucose-induced formation of fibronectin and type IV collagen by mesangial cells is PKC-dependent [145] and $\mathrm{PKC}-\beta_{\mathrm{I}}$ seems to be particularly up-regulated in glomerular cells exposed to high glucose [10]. Isoform-specific translocation of PKC has been confirmed in glomerular cells from diabetic rats, and there is now good evidence of PKC-mediated serine23 phosphorylation (accompanied by reduced activity) of the glomerular $\mathrm{Na}^{+}-\mathrm{K}^{+}$-ATPase [146]. This in turn affects cellular adhesion, vascular permeability and $\mathrm{Na}-\mathrm{H}$ transport. In addition, recent work has shown that high glucose stimulates mesangial cell proliferation through the $\mathrm{PKC}-\mathrm{NF} \kappa \mathrm{B}$ pathway [121].

Growth factors also play a key role in basement membrane thickening and increased ECM deposition, in particular TGF $\beta$ and connective tissue growth factor (CTGF) which increase collagen, fibronectin and laminin synthesis. Hyperglycaemia-induced expression of CTGF in cultured mesangial cells was blocked by a PKC inhibitor [147, 148], and up regulation of TGF $\beta$ by glucose involves PKC-dependent stimulation of AP-1 binding sites on the transcription factors $c$-fos and $c$-jun.

Interestingly, two therapeutic interventions that reduce proteinuria and slow the progression of diabetic nephropathy, aminoguanidine and the angiotensin converting enzyme inhibitor ramipril, both prevent diabetes-related increases in glomerular PKC activity [149], suggesting that this signal transduction pathway plays a central role in disease progression.

\section{Amelioration of hyperglycaemia-induced DAG-PKC activation in vascular tissues}

Vitamin E. Several in-vitro studies have shown that $d$ $\alpha$-tocopherol (vitamin E) prevents the rise in DAG and subsequent $\mathrm{PKC}$ activation in vascular cells exposed to high glucose [94]. Following i.p administration in diabetic rats, vitamin $\mathrm{E}$ ameliorated the increase in membrane PKC activity in the aorta [150], improved retinal blood flow [100] and reduced proteinuria [95]. The mechanism of this effect involves the stimulation of DAG kinase and the increased conversion of DAG to phosphatidic acid [97-99]; vitamin $\mathrm{E}$ has no effect on already-activated PKC
[100]. Impaired retinal microvascular blood flow correlates with DAG-PKC activation [89], and the therapeutic potential of high-dose vitamin $\mathrm{E}$ has recently been confirmed in a preliminary clinical study showing modest improvements in retinal perfusion [151].

Pharmacological inhibitors of PKC. Given that PKC is of such fundamental importance in cell signalling, it seemed highly unlikely only a few years ago that $\mathrm{PKC}$ inhibition would be a viable target for clinical drug development. First and second generation PKC inhibitors, such as the staurosporine-like compounds and isoquinolinesulphonamides (e.g. GF109203X), block the catalytic domain of PKC which carries a high degree of sequence homology with other kinases and are therefore non-specific for PKC. More recently, however, the recognition that PKC is a family of isoenzymes with significant biochemical and functional differences, coupled with mounting experimental evidence linking specific isozymes (e.g. PKC- $\beta$ ) with key pathological processes, has led to renewed interest in isoform-selective blockade of PKC activation using antisense oligonucleotides [133] or macrocyclic bis-indolylmaleimide compounds [152]. It has been shown that PKC- $\beta_{\text {II }}$ and PKC- $\beta_{\mathrm{I}}$ are preferentially activated in cardiovascular and renal tissues, respectively, in diabetes, and the chemical characterisation and in vivo profile of a highly-selective and orally active $\mathrm{PKC}-\beta$ inhibitor, LY333531 have been reported [153]. This compound showed considerable selectivity and reversibility for PKC- $\beta_{\mathrm{I}}$ and $-\beta_{\mathrm{II}}$ with half-maximal inhibitory constants ( $\mathrm{IC}_{50}$ values) of 4.7 and $5.9 \mathrm{mmol} / \mathrm{l}$, respectively, compared with $\mathrm{IC}_{50}$ values of $52 \mathrm{mmol} / \mathrm{l}$ for PKC$\eta$ and $300 \mathrm{mmol} / \mathrm{l}$ or more for all other PKC isoforms [153]. In diabetic rats, treatment with LY333531 had no effect on glucose-induced accumulation of DAG in the retina and glomeruli, but tissue PKC activities were significantly reduced in parallel with functional improvements in glomerular filtration rate, albuminuria and retinal blood flow. Low-dose therapy $(0.1 \mathrm{mg} / \mathrm{kg})$ reduced retinal PKC activity in diabetic rats but higher doses $(1$ and $10 \mathrm{mg} / \mathrm{kg}$ ) were required to achieve the same effect in the kidney. The drug had no effect on retinal and renal total PKC activity in non-diabetic animals, confirming that in normal conditions there is no preferential activation of PKC- $\beta$ [153].

The therapeutic profile of LY333531 has been evaluated in a range of experimental models related to diabetic vascular complications. In the eye, reductions in PKC activity were accompanied by improved blood flow [154] and the normalisation of diabetesrelated reductions in $\mathrm{Na}^{+}-\mathrm{K}^{+}$-ATPase and $\mathrm{Ca}^{2+}$-ATPase activities [155]. The role of PKC in mediating the ocular effects of VPF has also been confirmed: LY333531 reduces VPF-induced retinal permeability [142] and neovascularisation [156]. Preliminary clini- 
cal studies have shown favourable effects on retinal blood flow [157], and larger multicentre clinical trials to evaluate the effects of LY333531 on progression of diabetic retinopathy, especially maculopathy, are currently in progress.

In human mesangial cells cultured in high glucose medium, LY333531 attenuates PKC activation and normalises arachidonic acid release, $\mathrm{PGE}_{2}$ production and $\mathrm{Na}^{+}-\mathrm{K}^{+}$-ATPase activity [95]. Oral treatment in diabetic rats reduced the excess production of ECM proteins [95], and in $d b / d b$ mice LY333531 $10 \mathrm{mg} / \mathrm{kg}$ for 4 months reduced albumin excretion rate and mesangial expansion [158]. There is also interest in the effects of this compound on nerve conduction [159] and erectile dysfunction.

\section{Conclusions}

This family of multifunctional PKC isoenzymes plays a fundamental role in signal transduction and intracellular 'crosstalk' in many different tissues by phosphorylation and modification (up or down regulation) of enzymes, receptors, transcription factors and other kinases. In liver, skeletal muscle and adipose tissues, there is increasing evidence that PKC activation represents an important biochemical link between dysregulated lipid metabolism and insulin resistance. Different PKC isozymes could function as mediators (e.g. PKC- $\xi$ ) or inhibitors (e.g. PKC- $\theta$ and $-\varepsilon$ ) of insulin action. In muscle, most of the available evidence suggests that the accumulation of DAGs leads to PKC-mediated down regulation of the IR and downstream signalling events, including the IRS proteins. Glucose-induced de novo synthesis of DAG and PKC activation is likely to be an important mechanism of 'glucose toxicity', both in peripheral and pancreatic tissues.

Activation of the DAG-PKC pathway in cardiovascular and renal tissues is now recognised as a key biochemical event in the pathogenesis of diabetic complications, and hyperglycaemia-induced formation of palmitate-rich DAG seems to preferentially activate $\mathrm{PKC}-\beta$ in retinal, endothelial, VSM and glomerular cells. PKC activation adversely affects gene transcription (e.g. ECM protein synthesis), ion transport, vascular tone and endothelial permeability. The search for isozyme-selective PKC inhibitors is clearly feasible, as illustrated by the PKC- $\beta$ inhibitor LY333531, and offers exciting opportunities to block pathways involved in the initiation and progression of microangiopathy and macroangiopathy.

Literature Search: A search of the literature was undertaken using PubMed (Medline) using the following keywords PKC, insulin, complications, PKC isozymes, diabetes, heart, diacylglycerol, PKC inhibitor, insulin resistance, vascular.

\section{References}

1. Inoue M, Kishimoto A, Takai Y, Nishizuka Y (1977) Studies on a cyclic nucleotide-independent protein kinase and its proenzyme in mammalian tissues II. J Biol Chem 252: $7610-7616$

2. Housey GM, O'Brien CA, Johnson MD, Kirschmeier P, Weinstein IB (1987) Isolation of cDNA clones encoding protein kinase $\mathrm{C}$ : evidence for a protein kinase C-related gene family. Proc Natl Acad Sci USA 84: 1065-1069

3. Nishizuka Y (1988) The molecular heterogeneity of protein kinase $\mathrm{C}$ and its implications for cellular regulation. Nature 334: 661-665

4. Hug H, Sarre TF (1993) Protein kinase C isoenzymes: divergence in signal transduction? Biochem J 291: 329-343

5. Newton AC (1995) Protein kinase C: structure, function and regulation; minireview. J Biol Chem 270: 28495-28498

6. Pears C, Stabel S, Cazaubon S, Parker PJ (1992) Studies on the phosphorylation of protein kinase C- $\alpha$. Biochem J 283: 515-518

7. Nishizuka Y (1984) The role of protein kinase C in cell surface signal transduction and tumour promotion. Nature 308: 693-697

8. Nishizuka Y (1992) Intracellular signalling by hydrolysis of phospholipids and activation of protein kinase C. Science 258: 611-614

9. Nishizuka Y (1995) Protein kinase C and lipid signalling for sustained cellular responses. FASEB J 9: 484-496

10. Inoguchi T, Battan R, Handler E, Sportsman JR, Heath W, King GL (1992) Preferential elevation of protein kinase C isoform $\beta_{\text {II }}$ and diacylglycerol levels in the aorta and heart of diabetic rats. Differential reversibility to glycaemic control by islet transplantation. Proc Natl Acad Sci USA 89: 11059-11063

11. Mosthaf L, Kellerer M, Muhlhofer A, Mushack K, Seffer E, Haring HU (1996) Insulin leads to a parallel translocation of PI-3-kinase and protein kinase C- $\zeta$. Exp Clin Endocrinol Diabetes 104: 19-24

12. Standaert ML, Galloway L, Karnam P, Bandyopadhyay G, Moscat J, Farese RV (1997) Protein kinase C- $\zeta$ as a downstream effector of phosphatidylinositol 3-kinase during insulin stimulation in rat adipocytes. J Biol Chem 272: 30075-30082

13. Standaert ML, Bandyopadhyay G, Perez L et al. (1999b) Insulin activates protein kinases $\mathrm{C}-\xi$ and $-\lambda$ by an autophosphorylation-dependent mechanism and stimulates their translocation to GLUT4 vesicles and other membrane fractions in rat adipocytes. J Biol Chem 274: 25308-25316

14. Carlin S, Yang KXF, Donnelly R, Black JL (1999) Protein kinase $\mathrm{C}$ isoforms in human airway smooth muscle cells - A role for PKC- $\zeta$ in proliferation. Am J Physiol 276: L506L512

15. Donnelly R, Reed MJ, Azhar S, Reaven GM (1994) Expression of the major isoenzyme of protein kinase $\mathrm{C}$ in skeletal muscle, PKC- $\theta$, varies with muscle type and in response to fructose-induced insulin resistance. Endocrinology 135: 2369-2374

16. Schmitz-Peiffer C, Browne CL, Oakes ND et al. (1997) Alterations in the expression and cellular localisation of protein kinase $\mathrm{C}$ isozymes $\varepsilon$ and $\theta$ are associated with insulin resistance in skeletal muscle of the high-fat fed rat. Diabetes 46: 169-178

17. Griffin ME, Marcucci MJ, Cline GW et al. (1999) Free fatty acid-induced insulin resistance is associated with activation of protein kinase C- $\theta$ and alterations in the insulin signalling cascade. Diabetes 48: 1270-1274

18. Xia P, Inoguchi T, Kern TS, Engerman RL, Oats PJ, King GL (1994) Characterisation of the mechanism for the chronic activation of diacylglycerol-protein kinase $\mathrm{C}$ in diabetes and hypergalactosaemia. Diabetes 43: 1122-1129

19. Li W, Wang W, Liu X (1994) Comparative study of high-glucose effect on phosphatidylcholine hydrolysis of cultured reti- 
nal capillary pericytes and endothelial cells. Biochim Biophys Acta 1222: 339-347

20. Okumura K, Nishiura T, Awaji Y, Kondo J, Hashimoto H, Ito $\mathrm{T}$ (1991) 1,2-diacylglycerol content and its fatty acid composition in thoracic aorta of diabetic rats. Diabetes 40: 820-824

21. Shimomura T, Asoka Y, Oka M, Yoshida K, Nishizuka Y (1991) Synergistic action of diacylglycerol and unsaturated fatty acid for PKC activation: its possible implication. Proc Natl Acad Sci USA 88: 5149-5153

22. Diaz-Guerra MJM, Junco M, Bosca L (1991) Oleic acid promotes changes in the subcellular distribution of protein kinase $\mathrm{C}$ in isolated hepatocytes. J Biol Chem 266: 23568-23576

23. Yoshida K, Asoka Y, Nishizuka Y (1992) Platelet activation by simultaneous actions of diacylglycerol and unsaturated fatty acids. Proc Natl Acad Sci USA 89: 6443-6446

24. Lu X, Yang X-Y, Howard RL, Walsh JP (2000) Fatty acids modulate protein kinase $\mathrm{C}$ activation in porcine vascular smooth muscle cells independently of their effect on de novo diacylglycerol synthesis. Diabetologia 43: 1136-1144

25. Boneh A (1995) Possible role of protein kinase C in the pathogenesis of inborn errors of metabolism. J Cell Biochem 59: $27-32$

26. Considine RV, Caro JF (1993) Protein kinase C: mediator or inhibitor of insulin action. J Cell Biochem 52: 8-13

27. Considine RV, Nyce MR, Allen LE, Morales LM, Triester S, Serrano J, Colberg J, Lanza-Jacoby S, Caro JF (1995) Protein kinase $\mathrm{C}$ is increased in the liver of humans and rats with noninsulin-dependent diabetes mellitus: an alteration not due to hyperglycaemia. J Clin Invest 95: 2938-2944

28. Avignon A, Yamada K, Zhou X et al. (1996) Chronic activation of protein kinase $\mathrm{C}$ in soleus muscles and other tissues of insulin-resistant type II diabetic Goto-Kakizaki (GK), obese/aged, and obese Zucker rats. Diabetes 45: 1396-1404

29. Boggs KP, Farese RV, Buse MG (1991) Insulin administration in vivo increases 1,2-diacylglycerol in rat skeletal muscle. Endocrinology 128: 636-638

30. Cooper DR, Hernandez H, Kuo JY, Farese RV (1990) Insulin increases the synthesis of phospholipid and diacylglycerol and protein kinase $\mathrm{C}$ activity in rat hepatocytes. Arch Biochem Biophys 276: 486-494

31. Croquet F, Brehier A, Gil S, Davy J, Feger J (1996) Five isoenzymes of protein kinase $\mathrm{C}$ are expressed in normal and STZdiabetic rat hepatocytes: effect of phorbol 12-myristate 13-acetate. Biochim Biophys Acta 1315: 163-168

32. Nivet V, Antoine PJ, Amessou M et al. (1998) Increased expression of liver PKC- $\alpha$ in hypoinsulinaemic diabetic rats: a post-translational effect. Mol Cell Endocrinol 146: 177-185

33. Shmueli E, Alberti KGM, Record CO (1993) Diacylglycerol / protein kinase $\mathrm{C}$ signalling: a mechanism for insulin resistance? J Intern Med 234: 397-400

34. Bollag GB, Roth RA, Beaudoin J, Mochi-Rosen D, Koshland DE (1986) PKC directly phosphorylates the insulin receptor in vitro and reduces its protein-tyrosine kinase activity. Proc Natl Acad Sci USA 83: 5822-5824

35. Blackmore PF, Strickland WG, Exton JH (1986) Phosphorylation of glycogen synthase by protein kinase C. Biochem J 237: 235-242

36. Ishizuka T, Yamamoto M, Kajita K et al. (1993) Differential effects of ageing on protein kinase $\mathrm{C}$ activity in rat adipocytes and soleus muscle. Metabolism 42: 420-425

37. Qu X, Seale JP, Donnelly R (1999 a) Tissue- and isoform-specific effects of ageing in rats on protein kinase $\mathrm{C}$ in insulinsensitive tissues. Clin Sci (Colch) 97: 355-361

38. Qu X, Seale JP, Donnelly R (1999b) Tissue and isoform-selective activation of protein kinase $\mathrm{C}$ in insulin-resistant obese Zucker rats - effects of feeding. J Endocrinol 162: 207-214

39. Donnelly R, Chang H, Azhar S, Reaven GM (1995) Tissuedependent activation of protein kinase $\mathrm{C}$ in fructose-induced insulin resistance. Endocrine 3: 129-133

40. Heydrick SJ, Ruderman NB, Kurowski TG, Adams HB, Chen KS (1991) Enhanced stimulation of diacylglycerol and lipid synthesis by insulin in denervated muscle. Diabetes 40 : 1707-1711

41. Pillay TS, Xiao S, Olefsky JM (1996) Glucose-induced phosphorylation on the insulin receptor. J Clin Invest 97: 613-620

42. Filippis A, Clark S, Proietto J (1997) Increased flux through the hexosamine biosynthesis pathway inhibits glucose transport acutely by activation of PKC. Biochem J 324: 981-985

43. Vikman H-L, Kaartinen JM, Tuominer RK, Ohisalo J-J (1993) A possible role for protein kinase $\mathrm{C}$ in the regulatory differences between intra-abdominal and subcutaneous human adipose tissue. Clin Sci (Colch) 85: 265-268

44. Saltis J, Habberfield AD, Egan JJ et al. (1991) Role of protein kinase $\mathrm{C}$ in the regulation of glucose transport in the rat adipose cell. J Biol Chem 266: 261-267

45. Chin JE, Dickens M, Tavare JM, Roth RA (1993) Overexpression of protein kinase $\mathrm{C}$ isozymes $\alpha, \beta_{\mathrm{I}}, \gamma$ and $\varepsilon$ in cells overexpressing the insulin receptor. J Biol Chem 268: 6338-6347

46. Cortright RN, Muoio DM, Dohm GL (1997) Skeletal muscle lipid metabolism: a frontier for new insights into fuel homeostasis. Nut Biochem 8: 228-245

47. Phillips DIW, Caddy S, Iiic V, Fielding BA, Frayn KN, Borthwick AC, Taylor R (1996) Intramuscular triglyceride and muscle insulin sensitivity: evidence for a relationship in nondiabetic subjects. Metabolism 45: 947-950

48. Storlein LH, Borkman M, Jenkins AB, Pan DA, Campbell LV (1991) Diet and in vivo insulin action: of rats and man. Diabetes Nutr Metab 4: 227-240

49. Schmitz-Peiffer C, Oakes ND, Browne CL, Kraegen EW, Biden TJ (1997b) Reversal of chronic alterations of skeletal muscle protein kinase C from fat-fed rats by BRL49653. Am J Physiol 273: E915-E921

50. Goodyear LJ, Giogino F, Sherman LA, Carey JO, Smith RJ, Dohm GL (1995) Insulin receptor phosphorylation, insulin receptor substrate-1 phosphorylation, and PI-3-kinase activity are decreased in intact skeletal muscle strips from obese subjects. J Clin Invest 95: 2195-2204

51. Osada S-I, Mizuno K, Saido TC, Suzuki K, Kuroki T, Ohno S (1992) A new member of the protein kinase C family, nPKC$\theta$, predominantly expressed in skeletal muscle. Mol Cell Biol 12: $3930-3938$

52. Chang JD, Xu Y, Raychowdhury MK, Ware JA (1993) Molecular cloning and expression of a cDNA encoding a novel isoenzyme of protein kinase $\mathrm{C}(\mathrm{nPKC} \theta)$. J Biol Chem 268: 14208-14214

53. Qu X, Donnelly R (1997) Is insulin resistance in the spontaneously hypertensive rat related to changes in protein kinase $\mathrm{C}$ in skeletal muscle? Am J Hyperten 10: 1053-1057

54. Hotamisligil GS, Peraldi P, Budavari A, Ellis R, White MF, Spiegelman BM (1996) IRS-1-mediated inhibition of insulin receptor tyrosine kinase activity in TNF- $\alpha$ and obesity-induced insulin resistance. Science 271: 665-668

55. Kellerer M, Mushack J, Mischak H, Haring HU (1997) Protein kinase $C-\varepsilon$ enhances the inhibitory effect of TNF- $\alpha$ on insulin signalling in HEK293 cells. FEBS Lett 418: 119-122

56. Miura A, Ishizuka T, Kanoh Y et al. (1999) Effect of tumour necrosis factor- $\alpha$ on insulin signal transduction in rat adipocytes: relation to PKC- $\beta$ and $-\zeta$ translocation. Biochim Biophys Acta 1449: 227-238

57. Ciaraldi TP, Carter L, Mudaliar S, Kern PA, Henry RR (1998) Effects of tumour necrosis factor- $\alpha$ on glucose metabolism in cultured human muscle cells from nondiabetic and type 2 diabetic subjects. Endocrinology 139: 4793-4800

58. Van de Werve G, Proietto J, Jeanrenaud B et al. (1985) Tumour-promoting phorbol esters increase basal and inhibit insulin-stimulated lipogenesis in rat adipocytes without decreasing insulin binding. Biochem J 225: 523-527

59. Caro JF, Jenquin M, Long S (1992) Effects of phorbol esters on insulin receptor function and insulin action in hepatocytes. Mol Cell Biochem 109: 115-118

60. Gali RR, Pugazhenthi S, Khandelwal RL (1993) Reciprocal effects of the protein kinase $\mathrm{C}$ inhibitors staurosporine and 
H-7 on the regulation of glycogen synthase and phosphorylase in the primary culture of hepatocytes. Metabolism 42: $1475-1480$

61. Covera S, Jaspers S, Pasceri M (1991) Acute inhibition of insulin-stimulated glucose transport by the phosphatase inhibitor, okadaic acid. J Biol Chem 266: 9271-9275

62. Tanti J-F, Gremeaux T, Obberghen EV, Marchand-Brustel YL (1994) Serine/threonine phosphorylation of insulin receptor substrate-1 modulates insulin receptor signalling. J Biol Chem 269: 6051-6057

63. Standaert M, Bandyopadhyay G, Galloway L et al. (1999a) Effects of knockout of the protein kinase $\mathrm{C} \beta$ gene on glucose transport and glucose homeostasis. Endocrinology 140: 4470-4477

64. Bandyopadhyay G, Standaert ML, Zhao L et al. (1997) Activation of protein kinase $\mathrm{C}(\alpha, \beta$ and $\xi)$ by insulin in 3T3/L1 cells. J Biol Chem 272: 2551-2558

65. Bandyopadhyay G, Standaert M, Galloway L, Moscat J, Farese RV (1999) Evidence for involvement of protein kinase $\mathrm{C}$ (PKC)- $\zeta$ and noninvolvement of diacylglycerol-sensitive PKCs in insulin-stimulated glucose transport in L6 myotubes. Endocrinology 138: 4721-4731

66. Avignon A, Standaert ML, Yamada K, Mischak H, Spencer B, Farese RV (1995) Insulin increases mRNA levels of protein kinase $\mathrm{C}-\alpha$ and $-\beta$ in rat adipocytes and protein kinase $\mathrm{C}-\alpha,-\beta$ and $-\theta$ in rat skeletal muscle. Biochem J 308: $181-187$

67. Karisik A, Rothenberg PL, Yamada K, White MF, Kahn CR (1990) Increased protein kinase C activity is linked to reduced insulin receptor autophosphorylation in liver of starved rats. J Biol Chem 265: 10226-10231

68. Bassenmaier B, Mosthaf L, Mischak H, Ullrich A, Haring HU (1997) Protein kinase C isoforms beta- 1 and beta-2 inhibit the tyrosine kinase activity of the insulin receptor. Diabetologia 40: 863-866

69. Berti L, Mosthaf L, Kroder G et al. (1994) Glucose-induced translocation of protein kinase $\mathrm{C}$ isoforms in rat-1 fibroblasts is paralleled by inhibition of the insulin receptor tyrosine kinase. J Biol Chem 269: 3381-3386

70. Kellerer M, Mushack J, Seffer E, Mischak H, Ullrich A, Haring HU (1998) Protein kinase $\mathrm{C}$ isoforms $\alpha, \delta$ and $\theta$ require insulin receptor substrate- 1 to inhibit the tyrosine kinase activity of the insulin receptor in human kidney embryonic cells (HEK 293 cells). Diabetologia 41: 833-838

71. Strack V, Hennige AM, Krutzfeldt J et al. (2000) Serine residues 994 and 1023/25 are important for insulin receptor kinase inhibition by protein kinase $\mathrm{C}$ isoforms $\beta 2$ and $\theta$. Diabetologia 43: 443-449

72. Busch AK, Castan I, Degerman E, Tornqvist H, Mosthaf L (1998) Protein kinase C mediates hyperglycaemia-induced insulin resistance through serine phosphorylation of IRS-1. Diabetologia 41 [Suppl 1]: A10 (Abstract)

73. Muller HK, Kellerer M, Ermel B et al. (1991) Prevention by protein kinase $\mathrm{C}$ inhibitors of glucose-induced insulin-receptor tyrosine kinase resistance in rat fat cells. Diabetes 40: $1440-1448$

74. Itani SI, Zhou Q, Pories WJ, MacDonald KG, Dohm GL (2000) Involvement of protein kinase $C$ in human skeletal muscle insulin resistance and obesity. Diabetes 49: 1353-1358

75. Mosthaf L, Busch AK, Juhl LF et al. (1998) The insulin receptor is degraded by specific PKC isoforms. Diabetologia 41 [Suppl 1]: A10 (Abstract)

76. De Fea K \& Roth RA (1997) Protein kinase C modulation of insulin receptor substrate-1 tyrosine phosphorylation requires serine 612. Biochemistry 36: 12939-12947

77. Barthel A, Nakatani K, Dandekar AA, Roth RA (1998) Protein kinase $\mathrm{C}$ modulates the insulin-stimulated increase in Akt1 and Akt3 activity in 3T3-L1 adipocytes. Biochem Biophys Res Commun 243: 509-513

78. Bahr M, Spenlieken M, Bock M, von Holtey M, Kiehn R, Eckel J (1996) Acute and chronic effects of troglitazone on isolated rat ventricular cardiomyocytes. Diabetologia 39: 766-774
79. Zorozano A, Munoz P, Camps M, Mora C, Testar X, Palacin M (1996) Insulin-induced redistribution of GLUT4 glucose carriers in the muscle fibre: In search of GLUT4 trafficking pathways. Diabetes 45: S70-S81

80. Farese RV, Standaert ML, Ishizuka T, Bingzhi YU, Arnold TP, Cooper DR (1991) The role of diacylglycerol - protein kinase $\mathrm{C}$ signalling in insulin-stimulated glucose transport. Trans Assoc Am Physicians 104: 187-193

81. Goode N, Hughes K, Woodgett JR, Parker PJ (1992) Differential regulation of glycogen synthase kinase- $3 \beta$ by protein kinase C isotypes. J Biol Chem 267: 16878-16882

82. Tamagawa T, Niki H, Niki A (1985) Insulin release independent of a rise in cytosolic free $\mathrm{Ca}^{2+}$ by forskolin and phorbol ester. FEBS Lett 183: 430-432

83. Yu W, Niwa T, Fukasawa T et al. (2000) Synergism of protein kinase $\mathrm{A}$, protein kinase $\mathrm{C}$, and myosin light-chain kinase in the secretory cascade of the pancreatic beta cell. Diabetes 49: 945-952

84. Selbie LA, Schmitz-Peiffer C, Sheng Y, Biden TJ (1993) Molecular cloning and characterisation of $\mathrm{PKC}-\iota$, an atypical isoform of protein kinase $\mathrm{C}$ derived from insulin secreting cells $\mathrm{J}$ Biol Chem 268: 24296-24302

85. Tang SH, Sharp GW (1998) Atypical protein kinase C isozyme- $\zeta$ mediates carbachol-stimulated insulin secretion in RINm5F cells. Diabetes 47: 905-912

86. Zawalich WS, Zawalich K (1996) Regulation of insulin secretion by phospholipase C. Am J Physiol 271: E409-E416

87. Gregersen S, Thomsen J, Hermensen K (2000) Endothelin-1 potentiated insulin secretion: involvement of protein kinase $\mathrm{C}$ and the $\mathrm{ET}_{\mathrm{A}}$ receptor subtype. Metabolism 49: 264-269

88. Kaiser N, Sasson S, Feener EP et al. (1992) Differential regulation of glucose transport and transporters by glucose in vascular endothelial and smooth muscle cells. Diabetes 42: 80-89

89. Shiba T, Inoguchi T, Sportsman JR, Heath W, Bursell S, King GL (1993) Correlation of diacylglycerol and protein kinase C activity in rat retina to retinal circulation. Am J Physiol 265: E783-E793

90. Craven PA, Davidson MC, DeRubertis FR (1990) Increase in diacylglycerol mass in isolated glomeruli by glucose from de novo synthesis of glycerolipids. Diabetes 39: 667-674

91. Goekjian PE, Jirousek M (1999) Protein kinase C in the treatment of disease: signal transduction pathways, inhibitors, and agents in development. Curr Med Chem 6: 877-903

92. Ceolotto G, Gallo A, Miola M et al. (1999) Protein kinase C activity is acutely regulated by plasma glucose concentration in human monocytes in vivo. Diabetes 48: 1316-1322

93. Koya D, King GL (1998) Protein kinase C activation and the development of diabetic complications. Diabetes 47: 859-866

94. Kunisaki M, Bursell SE, Umeda F, Nawata H, King GL (1994) Normalisation of diacylglycerol-protein kinase C activation by vitamin $E$ in aorta of diabetic rats and cultured rat smooth muscle cells exposed to elevated glucose levels. Diabetes 43: 1372-1377

95. Koya D, Lee IK, Ishii H, Kanoh H, King GL (1997) Prevention of glomerular dysfunction in diabetic rats by treatment with d-alpha-tocopherol. J Am Soc Nephrol 8: 426-435

96. Roberts RE, McLean WG (1997) Protein kinase C isoenzyme expression in sciatic nerves and spinal cords of experimentally diabetic rats. Brain Res 754: 147-156

97. Tran K, Proulx PR, Chan AC (1994) Vitamin E suppresses diacylglycerol (DAG) level in thrombin-stimulated endothelial cells through an increase of DAG kinase activity. Biochim Biophys Acta 1212: 193-202

98. Lee IK, Koya D, Ishii H, Kanoh H, King GL (1999) d- $\alpha$-tocopherol prevents the hyperglycaemia induced activation of diacylglycerol-protein kinase $\mathrm{C}$ pathway in vascular smooth muscle cell by an increase in DAG kinase activity. Diabetes Res Clin Pract 45: 183-190

99. Ganz MB, Seftel A (2000) Glucose-induced changes in protein kinase $\mathrm{C}$ and nitric oxide are prevented by vitamin $\mathrm{E}$. Am J Physiol 278: E146-E152 
100. Kunisaki M, Bursell SE, Clermont AC et al. (1995) Vitamin E prevents diabetes-induced abnormal retinal blood flow via the diacylglycerol-protein kinase C pathway. Am J Physiol 269: E239-E246

101. Quyyumi AA (1998) Endothelial function in health and disease: new insights into the genesis of cardiovascular disease. Am J Med 105: 32S-39S

102. Standl E, Schnell O (2000) A new look at the heart in diabetes mellitus: from ailing to failing. Diabetologia 43: 1455-1469

103. Standl E, Balletshofer B, Dahl B et al. (1996) Predictors of 10year macrovascular and overall mortality in patients with NIDDM: the Munich General Practitioner Project. Diabetologia 39: 1540-1545

104. Chakravarthy U, Hayes R, Stitt A, McAuley E, Archer D (1998) Constitutive nitric oxide synthase expression in retinal vascular endothelial cells is suppressed by high glucose and advanced glycation end-products. Diabetes 47: 945-952

105. Park J-Y, Takahara N, Gabriele A et al. (2000) Induction of endothelin-1 expression by glucose: an effect of protein kinase C activation. Diabetes 49: 1239-1248

106. Takagi C, Bursell SE, Lin Y-W et al. (1996) Regulation of retinal haemodynamics in diabetic rats by increased expression and action of endothelin-1. Invest Ophthalmol Vis Sci 37: 2504-2518

107. Feke GT, Buzney S, Ogasawara H et al. (1994) Retinal circulatory abnormalities in type 1 diabetes. Invest Ophthalmol Vis Sci 35: 2968-2975

108. Sharma K, Danoff T, DePierro A, Ziyadeh FN (1995) Enhanced expression of inducible nitric oxide synthase in murine macrophages and glomerular mesangial cells by elevated glucose levels: possible mediation via protein kinase C. Biochem Biophys Res Commun 207: 80-88

109. Craven PA, Studer RK, DeRubertis FR (1995) Impaired nitric oxide release by glomeruli from diabetic rats. Metabolism 44: 695-698

110. Paul A, Doherty K, Plevin R (1997) Differential regulation by protein kinase $\mathrm{C}$ isoforms of nitric oxide synthase induction in RAW 264.7 macrophages and rat aortic smooth muscle cells. Br J Pharmacol 120: 940-946

111. Huang Q, Yuan Y (1997) Interaction of PKC and NOS in signal transduction of microvascular hyperpermeability. Am J Physiol 273: H2442-H2451

112. Oskarsson HJ, Hofmeyer TG, Coppey L, Yorek MA (1999) Effect of protein kinase $\mathrm{C}$ and phospholipase A2 inhibitors on the impaired ability of human diabetic platelets to cause vasodilation. Br J Pharmacol 127: 903-908

113. Xia P, Kramer RM, King GL (1995) Identification of the mechanism for the inhibition of $\mathrm{Na}, \mathrm{K}$-adenosine triphosphatase by hyperglycaemia involving activation of protein kinase $\mathrm{C}$ and cytosolic phospholipase $\mathrm{A}_{2}$. J Clin Invest 96: 733-740

114. Clark JD, Lin LL, Kriz RW et al. (1991) A novel arachidonic acid-selective cytosolic PLA2 contains a calcium-dependent translocation domain with homology to PKC and GAP. Cell 65: 1043-1051

115. Hopfner RL, Gopalakrishnan V (1999) Endothelin: emerging role in diabetic vascular complications. Diabetologia 42: 1383-1394

116. Yamada Y, Yokoda M (1997) Effects of protein kinase C activation and inhibition on endothelin-1 release from human aortic and pulmonary artery endothelial cells: comparison with effects on bovine endothelin- 1 and human prostaglandin $\mathrm{I}_{2}$ release. Am J Hyperten 10: 32-42

117. Jiang T, Pak E, Zhang H, Kline RP, Steinberg SF (1996) Endothelin-dependent actions in cultured AT-1 cardiac myocytes - the role of the $\varepsilon$ isoform of protein kinase C Circ Res 78: 724-736

118. Ikeda U, Takahashi M, Shimada K (1998) Monocyte-endothelial cell interaction in atherogenesis and thrombosis. Clin Cardiol 21: 11-14

119. Kreuzer J, Denger S, Schmidts A, Jahn L, Merten M, von Hodenberg E (1996) Fibrinogen promotes monocyte adhesion via a protein kinase $\mathrm{C}$ dependent mechanism. J Mol Med 74: $161-165$

120. Kalra VK, Shen Y, Sultana C, Rattan V (1996) Hypoxia induces PECAM-1 phosphorylation and transendothelial migration of monocytes. Am J Physiol 271: H2025-H2034

121. Park CW, Kim JH, Lee JW et al. (2000) High glucose-induced intercellular adhesion molecule-1 (ICAM-1) expression through an osmotic effect in rat mesangial cells is PKC-NFkB-dependent. Diabetologia 43: 1544-1553

122. Andrea JE, Walsh MP (1992) Protein kinase C of smooth muscle. Hypertension 20: 585-595

123. Williams B (1995) Glucose-induced vascular smooth muscle dysfunction: the role of protein kinase C. J Hyperten 13: 477-486

124. Williams B, Schrier RW (1992) Characterization of glucoseinduced in situ protein kinase $\mathrm{C}$ activity in cultured vascular smooth muscle cells. Diabetes 41: 1464-1472

125. Malhotra A, Reich D, Nakouzi A, Sanghi V, Geenen DL, Buttrick PM (1997) Experimental diabetes is associated with functional activation of protein kinase $\mathrm{C}$ epsilon and phosphorylation of troponin-I in the heart, which are prevented by angiotensin II receptor blockade. Circ Res 81: 1027-1033

126. Takeishi Y, Chu G, Kirkpatrick DM et al. (1998) In vivo phosphorylation of cardiac troponin-I by protein kinase C- $\beta$ II decreases cardiomyocyte calcium responsiveness and contractility in transgenic mouse hearts. J Clin Invest 102: 72-78

127. Williams B, Gallacher B, Patel H, Orme C (1997) Glucose-induced protein kinase $\mathrm{C}$ activation regulates vascular permeability factor mRNA expression and peptide production by human vascular smooth muscle cells in vitro. Diabetes 46 : $1497-1503$

128. Tomlinson DR (1999) Mitogen-activated protein kinases as glucose transducers for diabetic complications. Diabetologia 42: 1271-1281

129. Liu X, Wang J, Takeda N, Binaglia L, Panagia V, Dhalla NS (1999) Changes in cardiac protein kinase C activities and isozymes in streptozotocin-induced diabetes. Am J Physiol 277: E798-E804

130. Wakasaki H, Koya D, Schoen FJ et al. (1997) Targeted overexpression of protein kinase $\mathrm{C}-\beta_{\mathrm{II}}$ isoform in myocardium causes cardiomyopathy. Proc Natl Acad Sci USA 94: 9320-9325

131. Dorn GW, Souroujon MC, Liron T et al. (1999) Sustained in vivo cardiac protection by a rationally designed peptide that causes epsilon protein kinase C translocation. Proc Natl Acad Sci USA 96: 12798-12803

132. Berra E, Diaz-Meco MT, Dominguez I et al. (1993) Protein kinase $\mathrm{C}-\zeta$ is critical for mitogenic signal transduction. Cell 74: $555-563$

133. Liao D-F, Monia B, Dean N, Berk BC (1997) Protein kinase $\mathrm{C}-\zeta$ mediates angiotensin II activation of ERK1/2 in vascular smooth muscle cells. J Biol Chem 272: 6146-6150

134. Goldberg M, Zhang HL, Steinberg SF (1997) Hypoxia alters the subcellular distribution of protein kinase $C$ isoforms in neonatal rat ventricular myocytes. J Clin Invest 99: 55-61

135. Touyz RM, Schiffrin E (1997) Growth factors mediate intracellular signalling in vascular smooth muscle cells through protein kinase C-linked pathways. Hypertension 30: 1440-1447

136. Li P-F, Maasch C, Haller H, Dietz R, von Harsdorf R (1999) Requirement for protein kinase $\mathrm{C}$ in reactive oxygen speciesinduced apoptosis of vascular smooth muscle cells. Circulation 100: 967-973

137. Stasek JE, Patterson C, Garcia JGN (1992) Protein kinase C phosphorylates caldesmon-77 and vimentin and enhances albumin permeability across cultured bovine pulmonary artery endothelial monolayers. J Cell Physiol 153: 62-75

138. Nagpala PG, Malik A, Vuong PT, Lum H (1996) Protein kinase $\mathrm{C}-\beta_{\mathrm{I}}$ overexpression augments phorbol ester-induced increase in endothelial permeability. J Cell Physiol 166: 249-255 
139. Hempel A, Maasch C, Heintze U et al. (1997) High glucose concentrations increase endothelial cell permeability via activation of protein kinase C- $\alpha$. Circ Res 81: 363-371

140. Aiello LP, Avery RL, Arrigg PG et al. (1994) Vascular endothelial growth factor in ocular fluid of patients with diabetic retinopathy and other retinal disorders. N Engl J Med 331: 1480-1487

141. Xia P, Aiello LP, Ishii H et al. (1996) Characterization of vascular endothelial growth factor's effect on the activation of protein kinase $\mathrm{C}$, its isoforms, and endothelial cell growth. J Clin Invest 98: 2018-2026

142. Aiello LP, Bursell SE, Clermont A et al. (1997) Vascular endothelial growth factor-induced retinal permeability is mediated by protein kinase $\mathrm{C}$ in vivo and suppressed by an orally effective beta-isoform-selective inhibitor. Diabetes 46: 1473-1480

143. Hata Y, Rook SL, Aiello LP (1999) Basic fibroblast growth factor induces expression of VEGF receptor KDR through a protein kinase $\mathrm{C}$ and $\mathrm{p} 44 / \mathrm{p} 42$ mitogen-activated protein kinase-dependent pathway. Diabetes 48: 1145-1155

144. Tsopanoglou NE, Pipili-Synetos E, Maragoudakis ME (1993) Protein kinase $\mathrm{C}$ involvement in the regulation of angiogenesis. J Vasc Res 30: 202-208

145. Studer RK, Craven PA, DeRubertis F (1993) Role for protein kinase $\mathrm{C}$ in the mediation of increased fibronectin accumulation by mesangial cells grown in high-glucose medium. Diabetes 42: 118-126

146. Lal MA, Korner A, Matsuo Y et al. (2000) Combined antioxidant and COMT inhibitor treatment reverses renal abnormalities in diabetic rats. Diabetes 49: 1381-1389

147. Murphy M, Godson C, Cannon S et al. (1999) Suppression subtractive hybridization identifies high glucose levels as a stimulus for expression of connective tissue growth factor and other genes in human mesangial cells. J Biol Chem 274: 5830-5834

148. Riser BL, Denichilo M, Cortes P et al. (2000) Regulation of connective tissue growth factor activity in cultured rat mesangial cells and its expression in experimental diabetic glomerulosclerosis. J Am Soc Nephrol 11: 25-38

149. Osicka TM, Yu Y, Panagiotopoulos S et al. (2000) Prevention of albuminuria by aminoguanidine or ramipril in streptozoto- cin-induced diabetic rats is associated with the normalization of glomerular protein kinase C. Diabetes 49: 87-93

150. Kunisaki M, Fumio U, Nawata H, King GL (1996) Vitamin E normalises diacylglycerol-protein kinase $\mathrm{C}$ activation induced by hyperglycaemia in rat vascular tissues. Diabetes 45 [Suppl 3]: S117-S119

151. Bursell SE, Clermont AC, Aiello LP et al. (1999) High-dose vitamin $\mathrm{E}$ supplementation normalises retinal blood flow and creatinine clearance in patients with type 1 diabetes. Diabetes Care 22: 1245-1251

152. Jirousek MR, Gillig JR, Gonzalez CM et al. (1996) (s)-13[(dimethylamino)methyl]-10,11,14,15-tetrahydro-4,9: 16,21dimetheno-1H,13H-dibenzo[e,k]pyrrolo[3,4-h][1,4, 13]oxadiazacyclohexadecene-1,3(2H)-dione (LY333531) and related analogues: isozyme selective inhibitors of protein kinase $\mathrm{C}$ beta. J Med Chem 39: 2664-2671

153. Ishii H, Jirousek MR, Koya D et al. (1996) Amelioration of vascular dysfunctions in diabetic rats by an oral PKC- $\beta$ inhibitor. Science 272: 728-731

154. Bursell SE, Takagi C, Clermont AC et al. (1997) Specific retinal diacylglycerol and protein kinase $\mathrm{C}$ beta isoform modulation mimics abnormal retinal haemodynamics in diabetic rats. Invest Ophthalmol Vis Sci 38: 2711-2720

155. Kowluru RA, Jirousek MR, Stramm L, Farid N, Engerman RL, Kern TS (1998) Abnormalities of retinal metabolism in diabetes or experimental galactosaemia: relationship between protein kinase C and ATPases. Diabetes 47: 464-469

156. Danis RP, Bingaman DP, Jirousek M, Yang Y (1998) Inhibition of intraocular neovascularisation caused by retinal ischaemia in pigs by PKC- $\beta$ inhibition with LY333531. Invest Ophthalmol Vis Sci 39: 171-179

157. Aiello LP, Bursell SE, Devries T, Alatorre C, King GL, Ways K (1999) Protein kinase C $\beta$-selective inhibitor LY333531 ameliorates abnormal retinal haemodynamics in patients with diabetes. Diabetes 48 [Suppl 1]: A19 (Abstract)

158. Koya D, Haneda M, Nakagawa H et al. (2000) Amelioration of accelerated diabetic mesangial expansion by treatment with a PKC beta inhibitor in diabetic $d b / d b$ mice, a rodent model of type 2 diabetes. FASEB J 14: 439-447

159. Nakamura J, Kato K, Hamada Y et al. (1999) A protein kinase C-beta-selective inhibitor ameliorates neural dysfunction in STZ-induced diabetic rats. Diabetes 48: 2090-2095 